\title{
Emergence of new types of Theileria orientalis in Australian cattle and possible cause of theileriosis outbreaks
}

\author{
Joseph Kamau ${ }^{1 *}$, Albertus J de Vos $^{3}$, Matthew Playford ${ }^{4}$, Bashir Salim, Peter Kinyanjui ${ }^{2}$, Chihiro Sugimoto ${ }^{1}$
}

\begin{abstract}
Theileria parasites cause a benign infection of cattle in parts of Australia where they are endemic, but have, in recent years, been suspected of being responsible for a number of outbreaks of disease in cattle near the coast of New South Wales. The objective of this study was to identify and characterize the species of Theileria in cattle on six farms in New South Wales where disease outbreaks have occurred, and compare with Theileria from three disease-free farms in Queensland that is endemic for Theileria. Special reference was made to sub-typing of T. orientalis by type-specific PCR and sequencing of the small subunit (SSU) rRNA gene, and sequence analysis of the gene encoding a polymorphic merozoite/piroplasm surface protein (MPSP) that may be under immune selection. Nucleotide sequencing of SSU rRNA and MPSP genes revealed the presence of four Theileria genotypes: T. orientalis (buffeli), T. orientalis (ikeda), T. orientalis (chitose) and T. orientalis type 4 (MPSP) or type C (SSU rRNA). The majority of animals showed mixed infections while a few showed single infection. When MPSP nucleotide sequences were translated into amino acids, base transition did not change amino acid composition of the protein product, suggesting possible silent polymorphism. The occurrence of ikeda and type 4 (type C) previously not reported to occur and silent mutation is thought to have enhanced parasite evasion of the host immune response causing the outbreak.
\end{abstract}

\section{Background}

Theileria was first recorded in cattle in Australia in 1910 [1] and infection rates in endemic parts of the eastern states (QLD, NSW, Victoria) are high. In a survey in one region of New South Wales (NSW), 60\% of cattle were positive on blood smears [1] while cattle in endemic parts of Queensland (QLD) showed herd and animal seroprevalences of $75 \%$ and $41 \%$ respectively [2]. Infection is usually non-pathogenic but it was recognized more than 40 years ago that under certain, undefined conditions, the organism may become highly virulent [1]. Isolates of Theileria, identified as T. buffeli, have been recorded as common intra-erythrocytic parasites that are spread by members of the Haemaphysalis tick genus, with wide distribution throughout eastern Australia [3]. Due to the fact that only a few cases of clinical disease associated with Theileria infection had

\footnotetext{
* Correspondence: kamauvet@yahoo.com

'Department of Collaboration and Education, Research Center for Zoonosis Control, Graduate School of Veterinary Medicine, Hokkaido University, Japan Full list of author information is available at the end of the article
}

been reported prior to 2005, and transmission studies failed to elicit clinical disease in test subjects, Australian strains of Theileria were considered to be benign [3-5]. In recent years, a number of outbreaks were reported in cattle near the coast of NSW, characterized by anemia, jaundice, depression, abortion, mortality and the presence of Theileria in blood films [6]. Most of the outbreaks were seen in periparturient cattle that have recently been moved from inland to coastal areas.

The Theileria species present in Australia is referred to as T. buffeli [7] and belongs to the T. orientalis/sergenti/buffeli group of generally benign, cosmopolitan parasites found in many countries [8-12]. The taxonomic status of this group has been debated for many years. Based on serological and morphological grounds and transmission experiments, [3] suggested these parasites all belong to one species, T. orientalis, despite the fact that the Theileria sp. present in Japan, Korea and Russia is locally known as T. sergenti. T. sergenti is an invalid name taxonomically since it has been used to previously describe a parasite of sheep $[13,14]$. Based on

\section{Ciomed Central}


Major Piroplasm Surface Protein (MPSP) and 18S rDNA sequences, studies have designated these parasites as the $T$. sergenti/T. buffeli/T. orientalis group of benign theileria $[15,16]$. Comparison of the MPSP sequences of these parasites have shown that global parasites of this group can be classified into 1-8 types $[17,18]$. However, based on the MPSP sequence, one benign Theileria parasite from Brisbane, Australia (T. buffeli, Warwick) may as yet be in an unclassified group [18]. Within the pathogenic protozoans the most diverging proteins are those at the parasite surface that mediate physical recognition, response and modulation of the host [19]. In this regard, there was a need to amplify and sequence the MPSP gene to assess the antigenic variation in order shed light on how parasite is evolving in evading the host system.

At the onset of the outbreak, preliminary investigations confirmed the presence of parasite surface antigens identical to those found in outbreaks of clinical theileriosis in Japan. These antigens had not been previously found in Australian Theileria isolates [6]. The purpose of this study was to confirm if the antigens detected reflected the presence of parasites similar to those found in Japan, determine if the outbreaks reported in NSW was associated with an identifiable pathogen; and finally determine whether the Theileria species identified in the affected cattle are phylogenetically related to any of the 8 types such as T. buffeli (Warwick), to chitose type or, more notably, to ikeda type which is commonly found in Japan and Korea from anemic cattle suffering from bovine piroplasmosis. For the sake of simplicity, we will refer to the parasites as type 1-8 when using MPSP sequences.

\section{Materials and methods}

Samples collection and DNA extraction

Blood samples were collected from cattle of mixed ages known or suspected to be infected with Theileria in six farms in NSW and three farms in QLD. Sample locations are as indicated in the map Figure 1. Of the 45

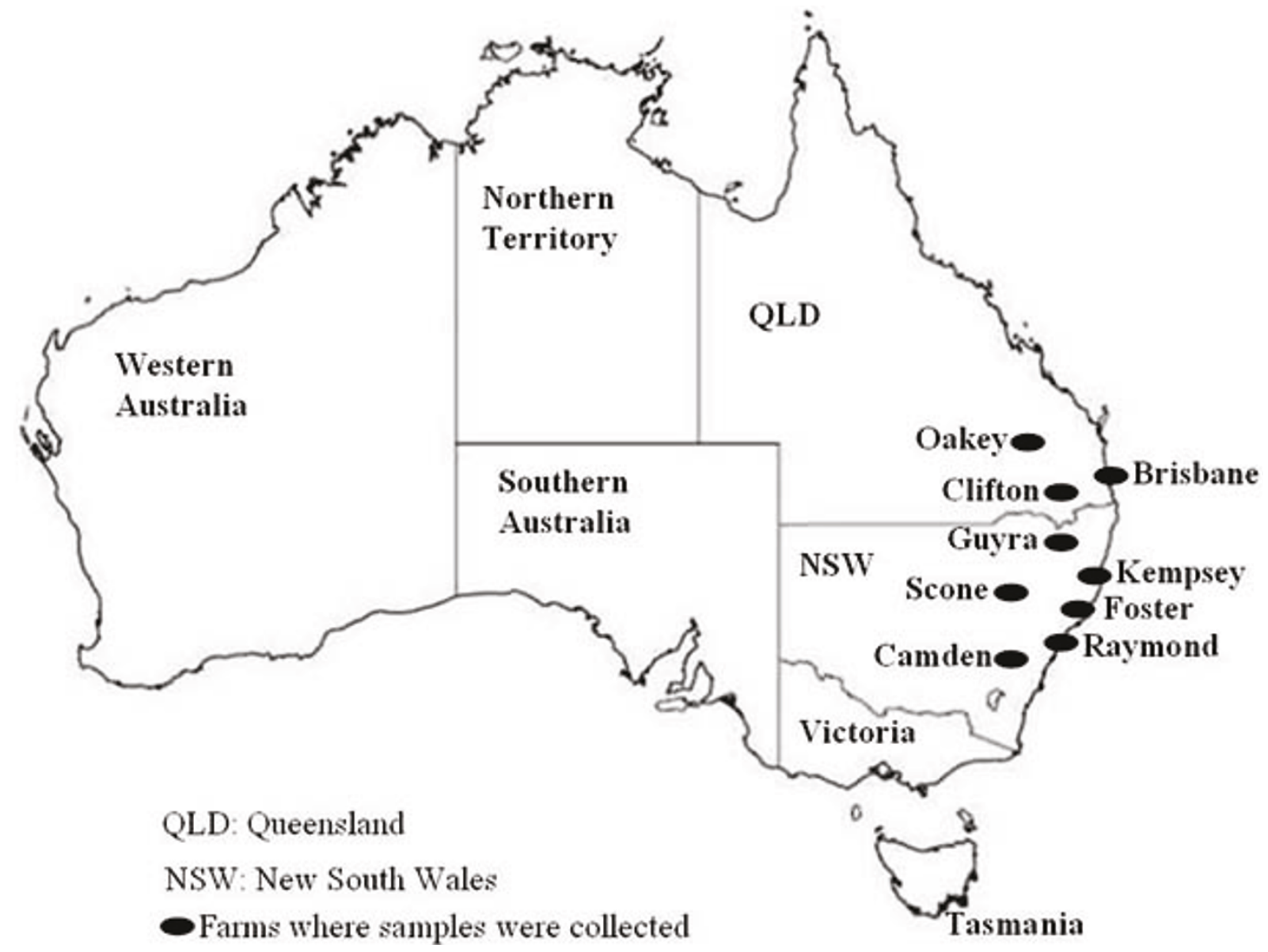

Figure 1 Australian map showing sampling locations in two states of Queensland and New South Wales. There were nine farms in total, three in Queensland and six in New South Wales. All the farms were in the coastal eastern part of Australia as indicated in the map. 
animals sampled, 17 were from QLD and 28 from NSW. Parasite DNA was extracted from whole blood samples using Qiagen QIAamp DNA Blood Kits (Qiagen, USA) and stored at $-20^{\circ} \mathrm{C}$ until use.

Investigation of alternative causes of haemolytic anaemia To investigate causes of haemolytic anaemia other than theileriosis, other alternatives considered and eliminated included babesiosis, anaplasmosis and trypanosomiasis. All cases were tested for the causative agents by smear examination and turned out to be negative. Chronic copper poisoning was eliminated because copper levels of affected cattle were in the normal range and none of the changes consistent with copper poisoning were seen on histopathology in the liver or kidney of autopsied cattle [6]. Other ingested/injected substances from grazing were excluded because there was no history of access/injection to such pastures. Immune mediated Autoimmune haemolytic anaemia in calves less than 6 months of age was discounted because most cases were diagnosed in cattle $>6$ months of age. Other causes of haemoglobinuria e.g. Bacillary haemoglobinuria (caused by Clostridium haemolyticum), Postparturient haemoglobinuria (a manifestation of low dietary phosphate intake) and leptospirosis were all eliminated as haemoglobinuria was not seen in any cases and tests for leptospirosis were negative or low consistent with vaccination. Bovine virus disease (BVD) is occasionally associated with anaemia but tested animals were negative.

\section{Polymerase chain reaction and sequencing}

The genomic DNA was subjected to PCR and sequencing for identification of the Theileria species and types present. The PCR primers used in this study are given in Table 1. Two genes were targeted for PCR: SSU
rRNA and MPSP. For the ssu rRNA gene, three typespecific sets of primers were used, each specific for one of the ikeda, chitose and buffeli types of the T. sergenti/ T. buffeli/T. orientalis group [20,21]. In addition universal Theileria SSU rRNA gene primers were used to PCR amplify the full-length gene of approximately $1800 \mathrm{bp}$, which was then cloned into a plasmid vector for sequencing. Internal ssu rRNA gene primers were used to facilitate sequencing of the cloned fragment [22]. In case of MPSP gene, a 776 bp fragment PCR amplified using primers universal for $T$. sergenti/T. buffeli/T. orientalis group. Conditions used for PCR amplifications were 10 $\mu \mathrm{l}$ of GoTaq Master Mix (Promega, Madison, WI, USA); $10 \mathrm{mM}$ of each primer scaled up to $20 \mu \mathrm{l}$ reaction mix. MPSP PCR products were then cloned into plasmid and sequenced. Thirty cycles of PCR were carried out using thermocycler (Takara co. Japan) with the following conditions: denaturation at $95^{\circ} \mathrm{C}$, for $15 \mathrm{~s}$; annealing at $57^{\circ} \mathrm{C}$ for $30 \mathrm{~s}$; and extension at $72^{\circ} \mathrm{C}$ for $1 \mathrm{~min}$. The PCR products of expected sizes were confirmed by electrophoresis on $1 \%$ agarose gel, visualized under UV and then ligated into pGEMT.

\section{SSU rRNA Gene sequence analysis}

The samples selected for SSU rRNA gene sequencing analysis were from herds with high parasitemia (1-7\%) and or those herds with reported cases of deaths. To minimize the amplification errors caused by Taq polymerase and increase the accuracy, a minimum of 5 clones from two PCR products were subjected to nucleotide sequencing. The complete nucleotide sequences were determined from both strands using 3130 XL Genetic Analyzer or 3130 Genetic Analyzer with the BigDyes Terminator cycle sequencing kit (Applied Biosystems). Nucleotide sequences were applied to a Basic Local Alignment Search Tool

Table 1 Primers used in identification of Theileria orientalis types

\begin{tabular}{|c|c|c|}
\hline Primer & Sequences & Expected Size \\
\hline \multicolumn{3}{|c|}{ SSU rRNA T. orientalis Type specific Forward Primer } \\
\hline Ts-lkeda & 5'-AAGGATCCGTCTCTGCTACCGCCGC-3' & 826bp (Kubota et al., 1996) \\
\hline Ts-Chitose & 5'-GCGGATCCTCATCGTCTCTGCAACT-3' & 831 bp “ \\
\hline Ts-Buffeli & 5'GCGGATCCGCTCTGCAACCGCAGAG-3' & 825 bp “ \\
\hline \multicolumn{3}{|c|}{ Type specific Universal Reverse Primer } \\
\hline Ts-R & 5'-TGTGAGACTCAATGCGCCTA-3' & \\
\hline \multicolumn{3}{|c|}{ MPSP ( Targeting entire Theileria orientalis group) } \\
\hline MPSP Forward Primer & 5'-CTTGCCTAGGATACTTCCT-3' & 776bp (Ota et al., 2009) \\
\hline MPSP Reverse Primer & 5'-ACGGCAAGTGGTGAGAACT-3' & " \\
\hline \multicolumn{3}{|l|}{ SSU (Theileria orientalis) } \\
\hline SSU rRNA Forward Primer & 5'-ACCTGGTTGATCCTGCCAGT-3' & 1800bp (Chae et al., 1998) \\
\hline SSU rRNA Reverse Primer & 5'-TAGGAAGACGTCCAAGTGGAATG-3' & $"$ \\
\hline \multirow[t]{2}{*}{ SSU rRNA Internal Primers (F\&R) } & F-5' ATTGGAGGGCAAGTCTGGTG-3' & 700bp (This study) \\
\hline & R-5'- CTCTCGGCCAAGGATAAACTCG-3' & " \\
\hline
\end{tabular}


(BLAST) in NCBI for homology analyses of Theileria MPSP genes. The sequences were edited using Genetyx Ver. 9 (http://www.sdc.co.jp/genetyx/) and aligned by clustalX2. The Neighbor Joining (NJ) phylogenetic tree was constructed using MEGA4 [23]. The molecular distances were estimated by the Kimura two parameter models [24]. The nodes were tested for robustness by 1000 bootstrap replications [25]. T. annulata and T. parva served as the out group. The representative sequences obtained were registered in the DDBJ/EMBL/ Genbank nucleotide sequence database under the assigned accession numbers AB520953-AB520958.

\section{MPSP Gene sequence analysis}

Further analysis to examine the diversity of the MPSP gene in samples representing the localities in NSW and QLD was undertaken. Based on diagnostic PCR and ssu rRNA sequences, samples for MPSP gene sequence analysis were selected considering their geographic origin and $T$. orientalis type detected by ssu rRNA sequence analysis. A total of 20 samples were sequenced using MPSP gene analysis. DNA sequencing analysis of positive clones was carried out to examine the diversity of the MPSP gene in these samples. Universal primers [6] capable to detecting all eight different types of $T$. orientalis types for MPSP allele amplifying 776-bp T. orientalis were used in sequencing.

\section{Results}

Diagnostic PCR using SSU rRNA species-specific primers New South Wales

The diagnostic PCR detected ikeda and chitose types In Kempsey property. On this property, there were eight positive cases, five with single ikeda infection, one case with chitose type while the others were mixed infection of ikeda and chitose. Parasitemia ranged from 1-7\% with one case of fatality reported. In Guyra properties, there were six positive animals in total. Two animals had either buffeli or chitose type while sixth one had co-infection of buffeli and chitose types. In Foster locations, there were three positive cases identified, two of which had mixed infection of chitose and ikeda, while the third one had mixed infections of all the three theileria orientalis types. Seven cases of fatalities were recorded in this property. The Scone property was negative for ikeda, but three cases were positive with chitose single infection while the other had mixed infection of chitose and buffeli. The Camden property had two positive cases with ikeda. On this property parasitemia ranged $2-7 \%$ and no fatality was reported. Percentage of T. orientalis types detected in New South Wales was ikeda (46\%), chitose (46\%) and $17.9 \%$ buffeli, majority of which mixed infections of ikeda and chitose.

\section{Queensland}

There were twelve animals sampled from a Brisbane property. Of these two had single infection with buffeli, three were positive with ikeda and chitose mixed infection, while four had mixed infection of chitose and buffeli types. Three animals were negative. Clifton property had three positive animals with mixed infection of chitose and buffeli types. There was only one sample from Oakey collected which was identified positive with buffeli type of infection. Percentage of T. orientalis types detected in Queensland was ikeda (5.9\%), chitose (52.9\%) and $58.8 \%$ buffeli, majority of which mixed infections of chitose and buffeli. The summary of the diagnostic PCR result is described in Tables 2 and 3.

\section{Small subunit ribosomal RNA (SSU rRNA) sequence analysis}

The sequence results (Figure 2) revealed the presence of four types of Theileria, type 2 (ikeda), type 1 (chitose), type 3 (buffeli) and type C. Previously type $C$ has been reported to occur in Japan and Korea [26]. When BLAST was done, animal numbers 4 (Forster) and 6 (Kempsey) showed high identity to Theileria chitosetype. Number 1 animal from Raymond Terrace showed high identity to Theileria buffeli-type of accession AB000272. Animal 41-Clifton was closely related to type $\mathrm{C}$ accession number U97051. Animal number 10 from Kempsey and 28 from Camden showed high identity to Theileria ikeda-type of accession U97048. Based on SSU rRNA sequences, the three types $[26,27]$ were confirmed in addition indentifying type $\mathrm{C}$.

\section{Major piroplasm surface protein (MPSP) sequence analysis}

The MPSP phylogenetic tree (Figure 2) was drawn based on nucleotides sequences. There was a number of single nucleotide polymorphism (SNPs) observed within and between group types. For example, (type 1) the chitose group had three clades within the group while type 2 (ikeda) had four clades forming the larger type 2 (ikeda). All these different clades within the group were as result of SNPs occurring. When the nucleotides were translated in protein, they did not result into amino acid profile change. Of interest to note are the sequences from animals number 41-Clifton and 45-Oakey which showed mosaic kind of pattern forming repeated sequences of chitose and ikeda suggesting the possibility of genetic recombination occurring. When BLAST was done, sample number 5, 6 and 12 from (Kempsey), 24 and 25 (Scone), 3 and 4 (Forster), 21 (Guyra) and 35 (Brisbane) all showed high identity to the registered database sequences of Theileria chitose-type accession D12689. Sample number 41 and 45, Clifton and Oakey respectively clustered with the classical benign type 
Table 2 List of isolate samples from outbreak regions in New South Wales, Australia, including geographic origin, Theileria orientalis type(s) identified by specific PCR and herd clinical history

\begin{tabular}{|c|c|c|c|c|c|}
\hline Sample No. & Location & Ikeda & Chitose & Buffeli & Herd Clinical History \\
\hline $1 *$ & $\begin{array}{l}\text { Raymond } \\
\text { Terrace }\end{array}$ & - & + & + & Anemia, Jaundice \\
\hline $2 *$ & $\begin{array}{l}\text { Forster } \\
\text { location } 1\end{array}$ & + & + & + & Shorthorn, 1 dead of 40,1 sick \\
\hline 3* & $\begin{array}{l}\text { Forster } \\
\text { location } 2\end{array}$ & + & + & - & Angus, 6 of 60 dead, 8 sick, anemia and jaundice \\
\hline $4^{*} \bullet$ & $\begin{array}{l}\text { Forster } \\
\text { location } 2\end{array}$ & + & + & - & " \\
\hline 5* & Kempsey & + & + & - & $\begin{array}{l}\text { Friesian, } 1 \text { dead of 150, } 3 \text { sick. Moved to property } 2 \text { months earlier. Anemia, jaundice, } \\
\text { condition loss. Parasitemia } 1-7 \%\end{array}$ \\
\hline $6^{*} \bullet$ & Kempsey & - & + & - & $"$ \\
\hline $7^{*}$ & Kempsey & + & - & - & $"$ \\
\hline $8^{*}$ & Kempsey & + & - & - & $"$ \\
\hline 9 & Kempsey & + & - & - & $"$ \\
\hline $10^{*}$ & Kempsey & + & - & - & $"$ \\
\hline 11 & Kempsey & + & - & - & $"$ \\
\hline $12^{*}$ & Kempsey & - & + & - & $"$ \\
\hline 13 & $\begin{array}{l}\text { Guyra } \\
\text { location } 1\end{array}$ & - & - & + & Cattle moved to property recently, some sick. Parasitemia of sampled cattle unknown \\
\hline 14 & $\begin{array}{l}\text { Guyra } \\
\text { location } 1\end{array}$ & - & - & - & " \\
\hline $15^{*}$ & $\begin{array}{l}\text { Guyra } \\
\text { location } 1\end{array}$ & + & - & - & $"$ \\
\hline 16 & $\begin{array}{l}\text { Guyra } \\
\text { location } 1\end{array}$ & - & - & - & $"$ \\
\hline $17^{*}$ & $\begin{array}{l}\text { Guyra } \\
\text { location } 1\end{array}$ & + & - & - & $"$ \\
\hline 18 & $\begin{array}{l}\text { Guyra } \\
\text { location } 1\end{array}$ & - & - & - & $"$ \\
\hline 19 & $\begin{array}{l}\text { Guyra } \\
\text { location } 2\end{array}$ & - & - & - & $\begin{array}{l}\text { Hereford, } 3 \text { adults of } 250 \text { dead, } 2 \text { sick. Moved to property } 3 \text { months earlier. Anemia, abortion. } \\
\text { Parasitemia of sampled animals unknown. }\end{array}$ \\
\hline 20 & $\begin{array}{l}\text { Guyra } \\
\text { location } 2\end{array}$ & - & + & + & $"$ \\
\hline $21^{*}$ & $\begin{array}{l}\text { Guyra } \\
\text { location } 2\end{array}$ & - & + & - & $"$ \\
\hline 22 & Scone & - & + & + & $\begin{array}{l}\text { Angus, } 8 \text { dead of } 180 \text { cows, } 12 \text { sick. Moved to property } 10 \text { months earlier. Anemia, jaundice. } \\
\text { Parasitemia } 1-7 \%\end{array}$ \\
\hline 23 & Scone & - & + & - & $"$ \\
\hline $24^{*}$ & Scone & - & + & - & $"$ \\
\hline $25^{*}$ & Scone & - & + & - & $"$ \\
\hline $26^{*}$ & Camden & + & - & - & Friesians, adults with jaundice, Anemia and fever after calving. Parasitemia 2-7\% \\
\hline 27 & Camden & - & - & - & $"$ \\
\hline $28 *$ & Camden & + & - & - & \\
\hline $\begin{array}{l}\text { Total } \\
\text { Percentages }\end{array}$ & & $46.4 \%$ & $46.4 \%$ & $17.9 \%$ & \\
\hline
\end{tabular}

4 D87201-Cheju-Korea, this type 4 is commonly found in Cheju Island in Korea but recent has been reported to occur in Okinawa island of Japan [6]. Samples 2 (Forster), 7 and 8 (Kempsey) and 27 (Guyra) showed high identity to ikeda types (AB218433 and D11046). In addition to high similarities revealed within each group of the four T. orientalis types, there were polymorphism differences observed within a specific type group. For 
Table 3 List of isolate samples from Non-outbreak regions in Queensland, Australia, including geographic origin, Theileria orientalis type(s) identified by specific PCR, and herd clinical history

\begin{tabular}{|c|c|c|c|c|c|}
\hline Sample No. & Location & Ikeda & Chitose & Buffeli & Clinical History \\
\hline 29 & Brisbane & - & - & - & $\mathrm{N} / \mathrm{A}$ \\
\hline 30 & Brisbane & - & - & - & N/A \\
\hline 31 & Brisbane & - & - & - & \\
\hline 32 & Brisbane & + & + & - & Heavy infection only after splenectomy \\
\hline 33 & Brisbane & + & - & - & $"$ \\
\hline 34 & Brisbane & - & + & + & $"$ \\
\hline $35 *$ & Brisbane & + & + & - & $"$ \\
\hline 36 & Brisbane & - & + & + & $"$ \\
\hline 37 & Brisbane & - & + & + & $"$ \\
\hline 38 & Brisbane & - & - & + & $"$ \\
\hline 39 & Brisbane & - & - & + & $"$ \\
\hline 40 & Brisbane & - & + & + & $"$ \\
\hline 41 & Clifton & - & - & - & $\mathrm{N} / \mathrm{A}$ \\
\hline 42 & Clifton & - & + & + & Cattle originating from Clifton and Oakey, SE Queensland stationed at Tick Fever Center \\
\hline 43 & Clifton & - & + & + & " \\
\hline $44^{*} \bullet$ & Clifton & - & + & + & $"$ \\
\hline $45^{*}$ & Oakey & - & - & + & $"$ \\
\hline Total Percentages & & $5.9 \%$ & $52.9 \%$ & $58.8 \%$ & \\
\hline
\end{tabular}

example, in type 1 (chitose), three distantly groups were found but falling within the larger type 1 group. Single nucleotide polymorphism (SNPs) within subsections in a group led to these sub-groups. The type 2-ikeda group had four sub-groups with animal number 15 Guyra being distantly from the rest of the larger ikeda group. The sample 1Raymond, although grouped in type 3-buffeli was distantly related to typical buffeli as shown by the long bar.

\section{Discussion}

Historically Theileria infection has not been associated with significant disease in Australian cattle. Consequently the identification of Theileria in blood smears from diseased cattle was initially dismissed as being unrelated to the disease outbreaks and investigations concentrated on identifying other possible causes. It was only when all other possible causes had been eliminated that a diagnosis of theileriosis was made. Consequently preliminary investigations had detected presence of parasite surface antigens identical to those found in clinical theileriosis in Japan. These parasite surface antigens were confirmed by the detection and subsequent identification of the ikeda, chitose and type 4/type $C$ isolates commonly associated with clinical cases in Japan and Korea. This may explain partly the cause of theileriosis.

There have been several epidemiological studies on theileriosis (T. orientalis) in many countries such as
Turkey, France, Spain [28-31], but only a few fatal cases due to $T$. buffeli have been reported to date $[8,32,33]$. Of the few cases reported, one fatal case was suspected that the clinical theileriosis might have been exacerbated by other factors compromising the immune competence of the animal such as concurrent bovine leukemia virus infection. In the study all possible causes of regenerative anemia such as babesiosis, anaplasmosis and trypanosomosis, bovine virus disease among others were eliminated.

$T$. orientalis of which ikeda type is a representative, seems to be closely associated with clinical cases in Japan and other Asian countries [34,35]. In New South Wales the epicenter of theileriosis outbreak, ikeda and chitose types were the predominant types detected accounting for $46.4 \%$ each. In contrast, Queensland had only $5.9 \%$ ikeda with and buffeli at $58.8 \%$. No case of theileriosis outbreak reported in Queensland. From our diagnostic PCR, the results indicate presence of ikeda may have been cause of theileriosis outbreak resulting in severe anaemia, high parasitemia and cases of deaths reported in some properties.

Clear taxonomical discrimination of parasites of this group, often referred as " $T$. orientalis/buffeli" has not been well established. As shown in Figure 3, parasites found in Australia in this study clearly separated into four clades (types) that are represented by type 2 (ikeda), type1 (chitose), type 3 (buffeli) and type 4 based 

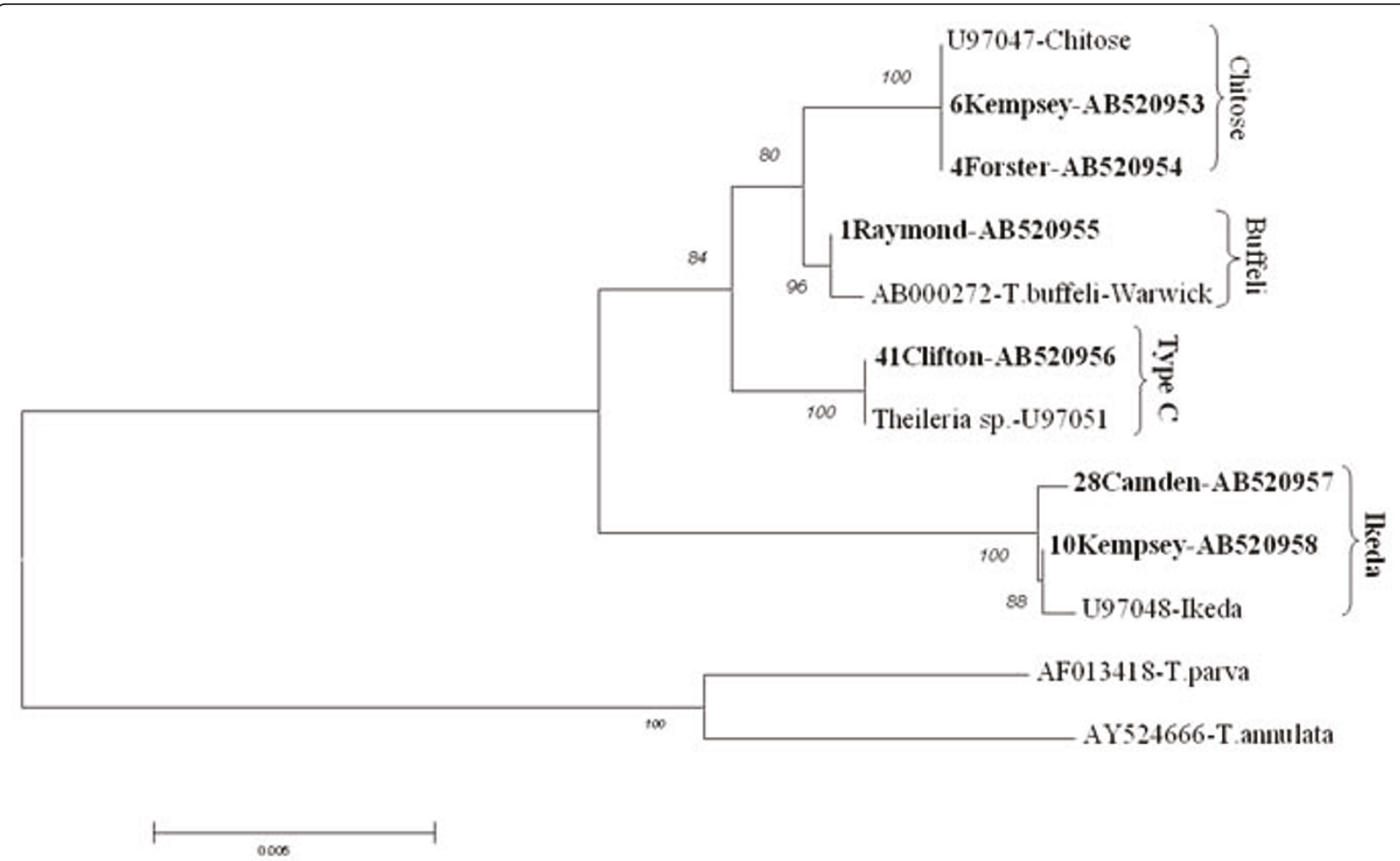

Figure 2 Phylogenetic relationships among Theileria types isolated in NSW and QLD based on SSU rRNA sequences. The tree was constructed using the neighbor-joining algorithm with molecular distances estimated by the Kimura- 2 parameter model. This tree shows chitose, buffeli and ikeda types in 3 different clades. One corresponding sequence each from T. parva (AF013418) and T. annulata (AY524666) served as outgroups. Bootstrap values are shown as percentages at each node based on 1000 replicates. Branch lengths correlate to the number of substitutions inferred according to the scale shown.

on MPSP sequences. Based on MPSP gene, animal 15 Guyra (AB520947) sequence is marginally separated from ikeda and other Australian parasites in this clade indicating increased number of SNPs observed when compared to other members in this group. There was evidence of SNPs observed in all the four type groups, though base transition did not result in amino acid change, suggesting silent mutation happening on the sequences coding for MPSP gene [36]. Provide evidence that silent SNPs can affect in vivo protein folding and, consequently, function that may in this case cause the variation of type of antigen detected. Silent mutation may explain the unique parasite surface antigens detected earlier in the preliminary investigations [6]. We hypothesize that this unique antigenic variation might have enhanced parasite's ability to evade host immune system [37] causing the parasite to become more virulent.

Many of the samples examined showed mixed populations of the different Theileria types. This is a common phenomenon that has also been noted in Japan [20,38], Korea [39] and Thailand [40] but its clinical significance is unknown. Mixed infections can occur both in the host or transmitting vector which results in different types interacting resulting in mutation due to competition to propagate and or evade host system. Recombination has been shown to occur frequently in Theileria species and has been described to occur within Tams 1 gene of T. annulata, homologue to MPSP in $T$. orientalis $[41,42]$. The possibility of genetic exchange where recombination result in an almost shuffling of sequence types is common. Our close examination of the MPSP sequence types when linked to SSU rRNA provided evidence of genetic reassortment i.e. when the MPSP sequences were linked to the same SSU rRNA sequence. The mode of vector transmission also might have played a part in the genetic re-assortment as observed in the MPSP gene sequence analysis [43]. Suggested that mixed infections are thought to disturb the host's immune system, since MPSP of ikeda and chitose are not serologically crossreactive.

Unlike the sporadic cases seen in the past, the recent outbreaks featured multiple cases, severe symptoms including aborted foetuses and many deaths in cattle of all ages with some individual herds losing 30\% of 


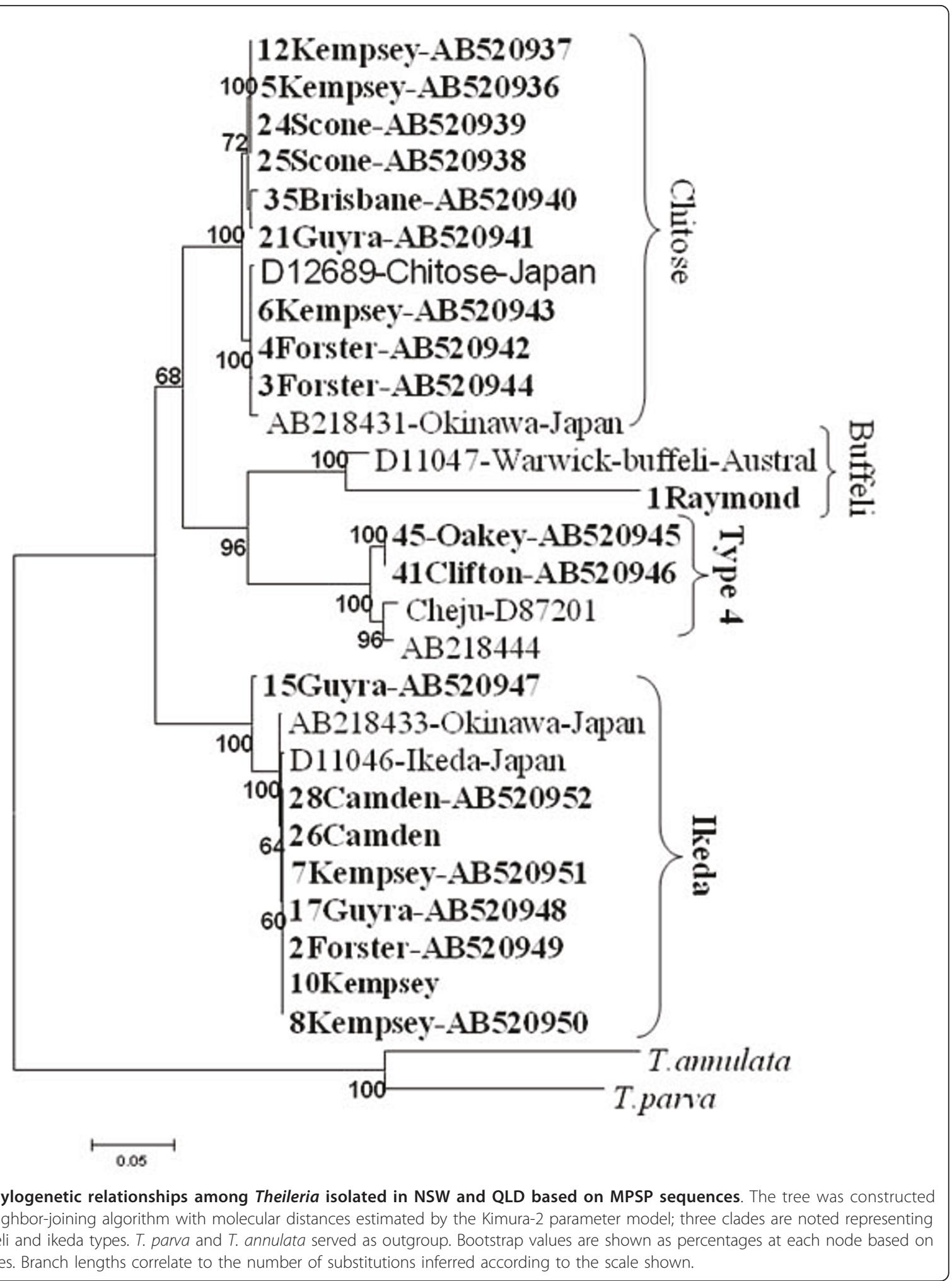


affected mobs. The majority of outbreaks in coastal areas have been in cattle that had been introduced from tick-free areas 4 to 6 weeks previously. The non-coastal outbreaks have mostly involved home-bred cattle on properties where coastal cattle had been introduced a few months previously. Global warming has been implicated in emergence of pathogens [44] that are adaptable or transmissible by vectors that otherwise would not have been possible. Changes in farm management including animal movements that accompany prolonged drought may also have compounded the outbreak of theileriosis.

\section{Acknowledgements}

This project was supported partly by the Commonwealth of Australia through the Australia-Japan Foundation of the Department of Foreign Affairs and Trade and in part by the Grants-in-Aid for Scientific Research and the Program of Founding Research Centers for Emerging and Re-emerging Infectious Diseases from the Ministries of Education, Culture, Sports, Science, and Technology, Japan. Ms Taryn Fletcher is thanked for collating the specimens and records from the different properties as well as extracting and forwarding the DNA specimens. Drs lan Poe, Graeme Fraser and Paul Freeman are thanked for their roles in accessing cattle on affected properties.

\section{Author details}

${ }^{1}$ Department of Collaboration and Education, Research Center for Zoonosis Control, Graduate School of Veterinary Medicine, Hokkaido University, Japan. ${ }^{2}$ Department of Biochemistry, School of Medicine, University of Nairobi, P.O. BOX 30197-00100, Nairobi, Kenya. ${ }^{3}$ Tick Fever Centre, Queensland Primary, Industries and Fisheries, 280 Grindle Rd, Wacol 4076, QLD, Australia.

${ }^{4}$ Dawbuts pty Itd, P.O. Box 1118, Camden, NSW 2570, Australia.

\section{Authors' contributions}

JK performed the experiments, data analysis and manuscript preparation. AJ conceived of the study, participated in the design and coordination of the experiment, provided with DNA samples from Queensland and helped draft of the manuscript. MP participated in the design and coordination of the experiment, provided with DNA samples from New South Wales, investigated alternative causes of haemolytic anaemia and helped draft manuscript. BS helped with construction of phylogenetic trees and interpretation. PK helped in revision of the manuscript. CS participated in the design of the experiment, supervisory role of the molecular work, provided the consumables and reagents required and helped in review of the manuscript. All authors read and approved the final manuscript.

\section{Competing interests}

The authors declare that they have no competing interests.

Received: 25 November 2010 Accepted: 21 February 2011

Published: 21 February 2011

\section{References}

1. Seddon HR, Albiston HE: Diseases of domestic animals in Australia. Part 4. Protozoan and virus diseases. Diseases of domestic animals in Australia. Part 4. Protozoan and virus diseases Canberra: Department of Health; 1966, viii, $+257 \mathrm{pp}$.

2. Stewart NP, Standfast NF, Baldock FC, Reid DJ, de Vos AJ: The distribution and prevalence of Theileria buffeli in cattle in Queensland. Aust Vet J 1992, 69:59-61.

3. Uilenberg G, Perie NM, Spanjer AAM, Franssen FFJ: Theileria orientalis, a cosmopolitan blood parasite of cattle: Demonstration of the schizont stage. Res Vet Sci 1985, 38:352-357.

4. Roberts FS: A systematic study of the Australian species of the genus Haemaphysalis Koch (Acarina: Ixodidae). Aust J Zool 1963, 11:35-80.
5. Stewart NP, Uilenberg G, De Vos AJ: Review of Australian species of Theileria, with special reference to Theileria buffeli of cattle. Trop Anim Health Prod 1996, 28:81-90.

6. Izzo MM, Poe I, Horadagoda NJdVA, House JK: Haemolytic anaemia in cattle in NSW associated with Theileria infections. Aust Vet J 2010, 88:45-51.

7. Callow LL: Animal health in Australia. Volume 5. Protozoal and rickettsial diseases. Australian Government Publishing Service, Canberra, A.C.T. 2601 Australia; 1984, ix, + 264pp.

8. Chae J, Allsopp BA, Waghela SD, Park J, Kakuda T, Sugimoto C, Allsopp MTEP, Wagner GG, Holman PJ: A study of the systematics of Theileria spp. based upon small-subunit ribosomal RNA gene sequences. J Parasitol Res 1999, 85:877-883.

9. Fujisaki K, Kamio T, Kawazu S, Stewart NP: Experimental transmission of Japanese Theileria sergenti and Australian $T$. buffeli by haemaphysaline tick species.Edited by: Dusbabek, F., Bukva, V. Modern Acarology. Academic Press, Prague; 1991:83-87.

10. Kawazu S, Sugimoto C, Kamio T, Fujisaki K: Analysis of the genes encoding immunodominant piroplasm surface proteins of Theileria sergenti and Theileria buffeli by nucleotide sequencing and polymerase chain reaction. Mol. Biochem. Parasitol 1992, 56:169-175.

11. Kawazu S, Sugimoto C, Kamio T, Fujisaki K: Antigenic differences between Japanese Theileria sergenti and other benign Theileria species of cattle from Australia (T. buffeli) and Britain (T. orientalis). Parasitol Res 1992, 78:130-135.

12. Onuma M, Kakuda T, Sugimoto C: Theileria parasite infection in East Asia and control of the disease. Comp Immunol Microbiol Infect Dis 1998, 21:165-177.

13. Morel PC, Uilenberg G: Sur la nomenclature de quelques Theileria (Sporozoa, Babesioidea) des ruminants domestiques. Revue d'Elevage et de Medicine des Pays Tropiquax 1981, 34:139-143.

14. Uilenberg G: Theileria sergenti 2011, 175(3-4):386

15. Kakuda T, Shiki M, Kubota S, Sugimoto C, Brown WC, Kosum C, Nopporn S, Onuma M: Phylogeny of benign Theileria species from cattle in Thailand, China and the U.S.A. based on the major piroplasm surface protein and small subunit ribosomal RNA genes. Int J Parasitol 1998, 28:1261-7.

16. Kim SJ, Tsuji M, Kubota S, Wei Q, Lee JM, Ishihara C, Onuma M: Sequence analysis of the major piroplasm surface protein gene of benign bovine Theileria parasites in East Asia. Int J Parasitol 1998, 28:1219-1227.

17. Ota N, Mizuno D, Kuboki N, Igarashi I, Nakamura Y, Yamashina $H_{\text {, }}$ Hanzaike T, Fujii K, Onoe S, Hata H, Kondo S, Matsui S, Koga M, Matsumoto K, Inokuma H, Yokoyama N: Epidemiological Survey of Theileria orientalis Infection in Grazing cattle in the Eastern Part of Hokkaido, Japan. J. Vet. Med. Sci 2009, 71:937-944.

18. Jeong W, Yoon SH, An DJ, Cho SH, Lee KK, Kim JY: A molecular phylogeny of the benign Theileria parasites based on major piroplasm surface protein (MPSP) gene sequences. Parasitology 2010, 137:241-9.

19. Templeton TJ: Whole-genome natural histories of apicomplexan surface proteins. Trends Parasitol 2007, 23:205-12.

20. Kubota S, Sugimoto C, Onuma M: A Genetic-Analysis of Mixed Population in Theileria-sergenti stocks and isolates using allele-specific polymerase chain-reaction. J Vet Med Sci 1995, 57:279-282

21. Kubota S, Sugimoto C, Kakuda T, Onuma M: Analysis of immunodominant piroplasm surface antigen alleles in mixed populations of Theileria sergenti and T. buffeli. Int J Parasitol 1996, 26:741-747.

22. Chae JS, Lee JM, Kwon OD, Holman PJ, Waghela SD, Wagner GG: Nucleotide sequence heterogeneity in the small subunit ribosomal RNA gene variable (V4) region among and within geographic isolates of Theileria from cattle, elk and white-tailed deer. Vet. Parasitol 1998, 75:41-52.

23. Tamura K, Dudley J, Nei M, Kumar S: MEGA4: Molecular Evolutionary Genetic Analysis (MEGA) software version 4.0. Mol. Bio. Evol 2007, 24:1596-1599.

24. Kimura M: A simple method for estimating evolutionary rates of base substitutions through comparative studies of nucleotide sequences. J. Mol. Evol 1980, 16:111-120.

25. Felsenstein J: Confidence interval limits on phylogenies: An approach using the bootstrap. Evolution 1985, 39:783-791.

26. Chae J, Kwon O, Holman PJ, Waghela SD, Wagner GG, Lee JM: Identical small subunit ribosomal gene nucleotide sequence of bovine Theileria 
(Korea and Japan) and Theileria buffeli (Marula, Kenya). The Korean Journal of Parasitology 1998, 36:47-53.

27. Chansiri K, Kawazu S, Kamio T, Terada Y, Fujisaki K, Philippe H, Sarataphan N: Molecular phylogenetic studies on Theileria parasites based on small subunit ribosomal RNA gene sequences. Vet. Parasitol 1999, 83:99-105.

28. Criado-Fornelio A, Buling A, Pingret J, Etievant M, Boucraut-Baralon C, Alongi A, Agnone A, Torina A: Hemoprotozoa of domestic animals in France: prevalance and molecular characterization. Vet. Parasitol 2009, 159:73-76.

29. Gimenez C, Casado N, Criado-Fornelio A, Alvarez de Miguel F, DominguezPenafiel G: A molecular survey of Piroplasmida and Hepatozoon isolated from domestic and wild animals in Burgos (Northern Spain). Vet Parasitol 2009, 162:147-150.

30. Altay K, Aydin MF, Dumanli N, Aktas M: Molecular detection of Theileria and Babesia infections in cattle. Vet. Parasitol 2008, 158:295-301.

31. Aktas M, Altay K, Dumanli N: A molecular survey of bovine Theileria parasite among apparently healthy cattle and with a note on the distribution of ticks in eastern Turkey. Vet. Parasitol 2006, 138:179-185.

32. Stockham SL, Kjemtrup AM, Conrad PA, Schmidt DA, Scott MA, Robinson TW, Tyler JW, Johnson GC, Carson CA, Cuddihee P: Theileriosis in a Missouri beef herd caused by Theileria buffeli: case report, herd investigation, ultrastructure, phylogenetic analysis, and experimental transmission. Vet Pathol 2000, 37:11-21.

33. Cossio-Bayagur R, Pillars R, Schlater J, Holman P: Theileria buffeli infection of a Michigan cow confirmed by small subunit ribosomal RNA gene analysis. Vet. Parasitol 2002, 105:105-110.

34. Shimizu S, Yoshiura N, Mizomoto T, Kondou Y: Theileria sergenti infection in dairy cattle. J. Vet. Med. Sci 1992, 54:375-377.

35. Shimizu S, Nojiri K, Matsunaga N, Yamane I, Minami T: Reduction in tick numbers (Haemaphysalis longicornis), mortality and incidence of Theileria sergenti infection in field-grazed calves treated with flumethrin pour-on. Vet. Parasitol 2000, 92:129-138.

36. Kimchi-Sarfaty C, Oh JM, Kim IW, Sauna ZE, Calcagno AM, Ambudkar SV, Gottesman MM: A "silent" polymorphism in the MDR1 gene changes substrate specificity. Science 2007, 315:525-8.

37. Komar AA: SNPs, Silent But Not Invisible. Science 2007, 315:466-7.

38. Kim J-Y, Yokoyama N, Kumar S, Inoue N, Inaba M, Fujisaki K, Sugimoto C: Identification of a piroplasm protein of Theileria orientalis that binds to bovine erythrocyte band 3. Mol. Biochem. Parasitol 2004, 137:193-200.

39. Baek B, Lee Y, Kim B: Antiparasitic effect of diminazene aceturate on Theileria sergenti types in calves. Korean Vet. Res 2002, 42:261-268.

40. Sarataphan N, Kakuda T, Chansiri K, Onuma M: Survey of benign Theileria parasites of cattle and buffaloes in Thailand using allele-specific polymerase chain reaction of major piroplasm surface protein gene. $J$ Vet Med Sci 2003, 65:133-135.

41. Gubbels MJ, Hong Y, van der Weide M, Qi B, Nijman IJ, Guangyuan L, Jongejan F: Molecular characterization of the Theileria buffeli/orientalis group. Int J Parasitol 2000, 30:943-952.

42. Weir W, Ben-Miled L, Karagenic T, Katzer F, Darghouth M, Shields B, Tait A: Genetic exchange and sub-structuring in Theileria annulata populations. Molecular and biochemical Parasitlogy 2007, 154:170-180.

43. Iwasaki T, Kakuda T, Sako Y, Sugimoto C, Onuma M: Differentiation and quantification of Theileria sergenti piroplasm types using type-specific monoclonal antibodies. J Vet Med Sci 1998, 60:665-669.

44. Parola P, Socolovschi C, Jeanjean L, Bitam I, Fournier P, Sotto A, Labauge P, Raoult D: Warmer Weather Linked to Tick Attack and Emergence of Severe Rickettsioses. PLoS Neglected Tropical Diseases 2008, 2:11.

doi:10.1186/1756-3305-4-22

Cite this article as: Kamau et al: Emergence of new types of Theileria orientalis in Australian cattle and possible cause of theileriosis outbreaks. Parasites \& Vectors 2011 4:22.

\section{Submit your next manuscript to BioMed Central and take full advantage of:}

- Convenient online submission

- Thorough peer review

- No space constraints or color figure charges

- Immediate publication on acceptance

- Inclusion in PubMed, CAS, Scopus and Google Scholar

- Research which is freely available for redistribution

Submit your manuscript at www.biomedcentral.com/submit
C Biomed Central 